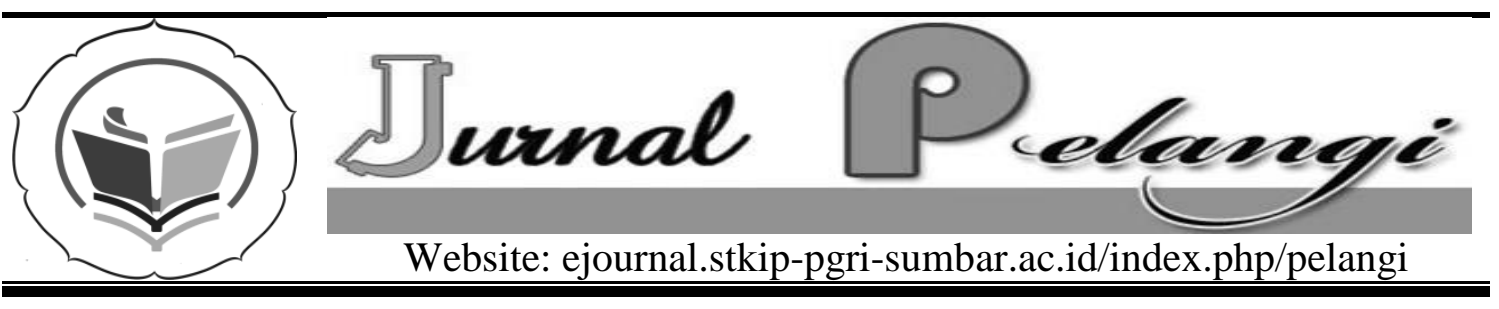

\title{
PENINGKATAN KEMAMPUAN MENULIS KARANGAN DESKRIPSI DENGAN PENDEKATAN LINGKUNGAN BAGI SISWA
}

\section{DARNIS}

SD Negeri 11 Pudung Kecamatan Ampek Nagari darnis@yahoo.co.id

\section{INFO ARTIKEL}

\section{Diterima:}

1 Desember 2015

Direview:

15 Desember 2015

Disetujui:

22 Desember 2015

Kata Kunci:

Kemampuan Menulis,

Karangan Deskripsi,

Pendekatan

Lingkungan
Keywords:

Writing Skill, Descriptive Text, Enviromental Approach

\begin{abstract}
Abstrak
Masalah yang dikemukakan dalam penelitian adalah bagaimana kemampuan menulis karangan deskripsi dengan pendekatan lingkungan bagi siswa. Tujuan penelitian adalah diharapkan terjadinya peningkatan hasil belajar menulis karangan deskripsi dengan pendekatan lingkungan. Penelitian ini adalah penelitian tindakan kelas dengan menggunakan pendekatan kualitatif. Penelitian tindakan ini dilaksanakan dalam dua siklus meliputi empat tahap yaitu perencanaan, pelaksanaan, pengamatan, refleksi. Subjek yang diteliti adalah siswa kelas IV SD Negeri 11 Pudung Kecamatan Ampek Nagari yang jumlah siswanya sebanyak 32 orang. Hasil penelitian ini menunjukan bahwa terjadi peningkatan rata-rata hasil belajar siswa yang pembelajarannya dengan menggunakan pendekatan lingkungan. Hal ini dapat dilihat dari nilai siswa yang diperoleh dari siklus I yaitu rata-rata nilai siswa 66,25 sedangkan pada siklus II nilai rata-rata siswa yaitu 80,31. Dari hasil penelitian tindakan kelas ini dapat diambil kesimpulan bahwa pembelajaran menulis karangan deskripsi dengan pendekatan lingkungan dapat meningkatkan hasil belajar siswa.
\end{abstract}


of grade IV student learning outcome average score by using an environmental approach. It can be seen from the student's average score in the first cycle i.e. 66.25. Meanwhile, the student's average score in the second cycle is 80.31. It means that the learning of descriptive text writing through an environmental approach can improve the grade IV student learning outcome.

\section{PENDAHULUAN}

Menulis di SD merupakan landasan bagi tingkat pendidikan yang lebih tinggi. Sebagai kemampuan yang mendasari tingkat pendidikan selanjutnya, menulis perlu mendapat perhatian guru, sebab jika dasarnya tidak kuat pada pendidikan berikutnya siswa akan mengalami kesulitan untuk dapat memperoleh dan memiliki pengetahuan.

Pembelajaran menulis di SD merupakan salah satu bagian dari pembelajaran bahasa Indonesia. Pembelajaran bahasa Indonesia terdiri atas empat aspek keterampilan berbahasa yaitu: menyimak, berbicara, membaca, dan menulis. Keempat aspek keterampilan berbahasa ini merupakan fokus tujuan pembelajaran bahasa Indonesia, hal ini berarti bahwa pembelajaran bahasa Indonesia bertujuan membina kemampuan menggunakan bahasa Indonesia dalam menyimak, berbicara, membaca dan menulis. Keempat aspek keterampilan ini dalam pelaksanaannya disajikan secara terpadu (Depdikbud, dalam Ritawati, 2007: 63).

Pembelajaran menulis di kelas IV SD dilaksanakan dengan mengacu pada tujuan yang terdapat dalam kurikulum bahasa Indonesia dengan kompetensi dasar pada aspek menulis adalah sebagai berikut: 1) menyelesaikan teks percakapan yang belum selesai, 2) menulis deskripsi, 3) mengisi formulir sederhana, 4) melanjutkan cerita narasi, 5) menulis surat, 6) menyusun paragraf, 7) menulis pengumuman, 8) menulis cerita rekaan, dan 9) membuat pantun. Pembelajaran menulis deskripsi bertujuan agar siswa mampu menggambarkan atau memerikan suatu objek sehingga pembaca merasakan keadaan yang dideskripsikan oleh penulis.

Menurut Rusyana

(1988:191) "Menulis merupakan kemampuan untuk menggungkapkan sesuatu atau pesan". Kemudian Costa (1985:103) juga "Menyatakan bahwa menulis dan berfikir merupakan dua kegiatan yang dilakukan secara bersama dan berulangulang". Muslich (2007:2) menyatakan bahwa menulis deskripsi adalah karangan yang berisi gambaran mengenai suatu hal atau keadaan sehingga pembaca seolah-olah melihat, mendengar, atau merasakan hal tersebut". Sejalan dengan pendapat di atas, Akhadiah M.K dkk (1998:7.30) menyatakan bahwa deskripsi itu berasal dari kata latin desceribe. Desceribe berarti menggambarkan atau memerikan suatu hal. Berdasarkan arti dari istilah tersebut dapat dikemukakan bahwa deskripsi adalah suatu bentuk karangan yang melukiskan memberikan sesuatu hal sejelas-jelasnya atau sehingga 
pembaca seolah-olah menyaksikan atau mengalaminya".

Berdasarkan observasi di SDN 11 Pudung Kecamatan Ampek Nagari pada hari Rabu tanggal 11 Maret 2015, diketahui bahwa kemampuan siswa dalam menulis karangan deskripsi masih rendah. Rendahnya kemampuan siswa dalam menulis karangan deskripsi disebabkan oleh kurangnya minat siswa dalam menulis karangan deskripsi karena guru hanya menggunakan metode konvensional dalam pembelajaran. Hendaknya dalam pembelajaran guru harus menggunakan berbagai pendekatan diantaranya pendekatan lingkungan, hal ini dikarenakan oleh kemampuan siswa kelas IV SD yang masih berada dimasa operasional konkrit dan masih membutuhkan benda nyata untuk mengembangkan imajinasinya dalam menulis karangan deskripsi.

Semi (1990:42) berpendapat bahwa deskripsi adalah "tulisan yang bertujuan memberikan perincian dan detail tentang objek sehingga memberikan pengaruh pada sensivitas dan imajinasi pembaca seolah-olah ikut melihat, mendengarkan, merasakan serta mengalami lansung objek tersebut". Deskripsi adalah penggambaran. Dalam menulis karangan deskripsi disebar sepanjang cerita, hindari jadi otak pembaca dengan menyisipkan kesimpulan dan penafsiran sendiri. Harus diingat bahwa penulis adalah mata, hidung dan telinga bagi pembaca. Deskripsi adalah tulisan yang bertujuan memberikan perincian dan detail tentang objek sehingga memberi pengaruh pada sensivitas dan amjinasi baca atau pendengar.
Ada dua jenis tulisan deskripsi, yaitu 1) deskripsi ekspositoris atau deskripsi teknis, dan 2) deskripsi sastra. Menurut Lubis (2008:1) deskripsi ekspositoris atau deskripsi teknis, yaitu deskripsi yang tidak menimbulkan imajinasi, kesan, dan pengaruh kepada pembaca. Bahasa yang digunakan adalah bahasa yang formal dan lugas. Bentuk ini kadang-kadang sukar di bedakan dengan eksposisi, bahkan hampir sama dengan eksposisi, sedangkan deskripsi sastra yaitu menimbulkan imajinasi, kesan, dan pengaruh kepada para pembaca. Dengan kata lain deskripsi sastra berusaha menciptakan suatu penghayatan terhadap objek tersebut melalui imajinasi pembaca. Dalam penelitian tindakan ini penulis selaku peneliti memfokuskan kepada deskripsi ekspositoris.

Langkah-langkah yang dilakukan dalam menulis karangan deskripsi menurut Muslich (2007:3) sebagai berikut: "1) tentukan objek atau tema yang akan dideskripsikan, 2) tentukan tujuan, 3) tentukan aspek-aspek yang akan dideskripsikan dengan melakukan pengamatan, 4) susunlah aspek-aspek tersebut kedalam arutan yang baik, 5) apakah lokasi, urutan waktu, atau urutan menurut kepentingan, dan 6) memgembangkan kerangka menjadi deskripsi “. Eny (2004:61) menyatakan bahwa "langkah-langkah mengarang adalah: 1) menentukan tema, 2) merumuskan tujuan, 3) mengumpulkan bahan, 4) membuat kerangka karangan, dan 5) mengembangkan kerangka karangan menjadi karangan yang utuh".

Menurut Daud (2008) "pendekatan pembelajaran yang berusaha untuk 
meningkatkan keterlibatan siswa melalui pendayagunaan lingkungan sebagai program belajar, atau dengan kata lain kegiatan pembelajaran akan menarik perhatian siswa jika apa yang dipelajari diangkat dari lingkungan, sehingga apa yang dipelajari berhubungan dengan kehidupan dan berfaedah bagi lingkungannya". Selanjutnya Nasution (2003:5.4) menyatakan "pendekatan lingkungan adalah penggunaan atau pemanfaatan lingkungan guna memperlancar atau mencapai keberhasilan dalam belajar. Moejodjiono (1992:16) mengemukakan bahwa "pendekatan adalah pendekatan yang berorientasi pada lingkungan dan fenomena melalui penglihatan, pendengaran, percobaan penciuman dan perasa atau pengecap". Pengertian pendekatan lingkungan adalah sebagai berikut: Merupakan pendekatan pembelajaran dimana siswa diajak secara langsung berhadapan dengan lingkungan di mana fakta atau gejala alam tersebut berada. Pemanfaatan lingkungan sangat penting dalam pembelajaran bahasa indonesia, karena lingkungan dapat dipandang sebagai sasaran belajar atau merupakan obyek yang dipelajari anak.

Pendekatan lingkungan melibatkan panca indera seseorang dalam ini Moejodjiono (1992:16) mengemukakan tentang keefektifan dari pendekatan lingkungan sebagai berikut: Melalui indera penglihatan seseorang dapat mementukan warna dan letak dari suatu objek, melalui indera pendengaran orang dapat mengetahui bunyi dari suatu objek/benda melalui indera pengecap seseorang dapat mengetahui kasar atau halusnya suatu objek, dan melalui indera penciuman seseorang dapat mengetahui harum atau busuknya sesuatu. Simpulan dari pengertian pendekatan lingkungan di atas yaitu pemanfaatan/menggunakan sesuatu yang ada di lingkungan baik berupa keadaan fisik maupun non fisik sebagai salah satu usaha untuk mencapai tujuan yang diinginkan.

Pembelajaran menulis karangan deskripsi pada pembelajaran Bahasa Indonesia dengan menggunakan pendekatan lingkungan dapat dilaksanakan dengan baik. Guru menceritakan manfaat menulis dan menjelaskan pengertian karangan deskripsi beserta contohnya. Dari keterangan yang diberikan guru maka siswa diharapkan mengerti apa yang dimaksud dari menulis karangan deskripsi tersebut. Setelah membuat karangan siswa memperbaiki karangan dari segi Ejaan yang Disempurnakan (EYD). Kemudian siswa membaca karangan deskripsi yang telah diperbaiki di depan kelas dan menambahkan kekurangan yang terdapat pada karangan teman dan karangannya sendiri, selanjutnya siswa menyalin kembali karangan yang telah disempurnakan ke dalam buku latihan. Itulah kegiatan yang dilakukan untuk menulis karangan deskripsi dengan pendekatan lingkungan.

Menurut Burs dalam Saleh (2006:168) ada beberapa cara yang dapat dilakukan dalam menulis karangan yaitu: bertanya jawab atau berdiskusi, memantau kegiatan siswa pada tiap proses menulis baik pramenulis, penulisan, dan pasca penulisan dengan menggunakan obsevasi catatan lapangan dan ceklis, serta memantau hasil 
karangan siswa dengan asesmen portifolio.

Pembelajaran menulis karangan deskripsi untuk siswa di kelas IV SD termasuk jenis pembelajaran menulis lanjutan. Tujuan utamanya adalah menggupayakan siswa dapat memahamim cara menulis untuk pemahaman yang lebih tinggi baik secara lisan maupun tulisan. Pembelajaran menulis karangan deskripsi dengan menggunakan pendekatan lingkungan dapat dilakukan dengan tiga tahap sebagai berikut: (1) pramenulis, (2) penulisan, dan (3) pascapenulisan.

Pada tahap pramenulis siswa diberi kesempatan secara bebas untuk mengembangkan skemata dalam menentukan objek yang diamati. Hal ini dapat dilakukan dengan mengemukakan tujuan dari objek yang dideskripsikan, menentukan bagian objek yang dideskripsikan, mendeskripsikan objek yang telah dipilih, dan membuat kerangka deskripsi.

Pada tahap penulisan siswa diberi kesempatan untuk mengembangkan kerangka karangan menjadi sebuah karangan deskripsi. Dalam kegiatan menulis karangan deskripsi digunakan pendekatan lingkungan, agar siswa lebih termotifasi dan merasa senang dalam melakukan kegiatan menulis. Kemudian siswa menuliskan karangan deskripsi dengan menggunakan kalimat efektif dan cermat serta bernilai sastra yang mudah dipahami.

Pada tahap pasca penulisan siswa membaca ulang karangan deskripsi (penilaian), dan memperbaiki kalimat dalam karangan sesuai dengan EYD yang benar. Kemudian siswa menyalin kembali karangan yang sudah diperbaiki, dan mempublikasikan karangan deskripsi yang telah dibuatnya. Berdasarkan uraian di atas, tujuan penelitian tindakan kelas ini adalah "untuk meningkatan kemampuan menulis karangan deskripsi dengan pandekatan lingkungan bagi siswa kelas IV SD Negeri 11 Pudung Kecamatan Ampek Nagari”.

\section{METODE PENELITIAN}

Penelitian dilakukan di SD Negeri 11 Pudung Kecamatan Ampek Nagari karena peneliti adalah guru kelas di SD Negeri 11 Pudung. Subjek dalam penelitian ini adalah siswa kelas IV SD Negeri 11 Pudung Kecamatan Ampek Nagari yang berjumlah 32 orang.

Penelitian ini merupakan penelitian tindakan kelas karena kajiannya bersifat reflektif. Reflektif dilakukan untuk meningkatkan kemantapan rasional serta memperdalam pemahaman dan memperbaiki tindakan-tindakan pembelajaran. Rangkaian langkah terdiri dari: studi pendahuluan, refleksi awal, perencanaan, tindakan, pengamatan, dan refleksi.

\section{Tahap Perencanaan}

Kegiatan ini dimulai dengan merumuskan rancangan tindakan pembelajaran yaitu: 1) Menyusun rancangan berupa model pembelajaran, hal ini meliputi: (a) tujuan pembelajaran, (b) memilih dan menetapkan materi, (c) kompetensi dasar, indikator, memilih dan menetapkan materi, (d) kegiatan belajar mengajar, (e) memilih dan menetapkan media dan sumber 
pembelajaran, dan (f) penilaian. 2) menyusun indikator, deskriptor, dan kriteria pembelajaran menulis karangan deskripsi dengan menggunakan pendekatan lingkungan. 3) menyusun data berupa: observasi, hasil belajar siswa (penugasan), dan pencatatan lapangan, serta 4) melakukan kolaborasi guru untuk perencanaan, melaksanakan dan penilaian pembelajaran menulis karangan deskripsi dengan pendekatan lingkungan.

\section{Tahap Pelaksanaan}

Tahap ini dimulai dari pelaksanaan pembelajaran menulis karangan deskripsi dengan pendekatan lingkungan sesuai dengan rencana. Penelitian ini dilakukan dengan tiga siklus. Kegiatan dilakukan guru kelas sebagai praktisi dan peneliti sebagai observer. Praktisi melaksanakan kegiatan pembelajaran di kelas berupa kegiatan interaksi antara guru dan siswa dan siswa dengan guru.

Kegiatan yang dilakukan pada tahap pramenulis sebagai berikut: 1) menentukan objek, 2) mengemukakan tujuan dari objek yang dideskripsikan, 3) menentukan bagian objek yang dideskripsikan, 4) mendeskripsikan objek yang telah dipilih, dan 5) membuat kerangka deskripsi dari objek. Kegiatan pada tahap pramenulis ini dilakukan diluar kelas.

Kegiatan yang dilakukan pada tahap penulisan yaitu: 1) mengembangkan kerangka karangan menjadi deskripsi, 2) menuliskan karangan deskripsi dengan menggunakan kalimat efektif dan cermat serta bernilai sastra yang mudah dipahami. Kegiatan pada tahap penulisan ini dilakukan di dalam kelas.
Kegiatan yang dilakukan pada saat pascapenulisan sebagai berikut:1) membaca ulang karangan deskripsi (penilaian), 2) memperbaiki kalimat sesuai EYD yang benar, 3) menyalin kembali karangan yang sudah diperbaiki, dan 4) mempublikasikan karangan deskripsi.

\section{Tahap Pengamatan}

Pengamatan terhadap pembelajaran bersamaan dengan pelaksanaan tindakan. Hal ini dilaksanakan secara intensif, objektif, dan sistematis. Pengamatan lakukan oleh guru pada waktu peneliti melaksanakan tindakan pembelajaran menulis karangan deskripsi dengan pendekatan lingkungan siswa kelas IV. Pengamatan dilakukan oleh observer, ditulis dalam lembar observasi. Pengamatan dilakukan mulai dari satu siklus, sampai siklus tiga. Pengamatan yang dilakukan pada satu siklus dapat mempengaruhi penyusunan tindakan pada siklus selanjutnya. Hasil pengamatan ini kemudian didiskusikan dengan guru dan diadakan refleksi untuk perencanaan siklus berikutnya.

\section{Tahap Refleksi}

Refleksi diadakan setiap satu tindakan berakhir. Guru dan peneliti mengadakan diskusi terhadap tindakan yang baru dilakukan. Hal-hal yang didiskusikan adalah sebagai berikut: (1) menganalisis tindakan yang baru dilakukan, (2) mengulas dan menjelaskan perbedaan rencana pelaksanaan dan pelaksanaan tindakan yang telah dilakukan, dan (3) melakukan intervensi, pemaknaan, dan penyimpulan data yang diperoleh. Hasil refleksi 
bersama ini dimanfaatkan sebagai masukan pada tindakan selanjutnya. Selain itu, hasil kegiatan refleksi setiap tindakan digunakan untuk menyusun simpulan terhadap hasil dari tindakan tersebut.

Instrumen yang digunakan dalam penelitian ini adalah lembar observasi, penugasan, dan pencatatan lapangan. Data di dalam penelitian ini dianalisis dengan model alir. Penyimpulan dilakukan setelah kegiatan reduksi dan penyajian data. Simpulan pertama dan kedua dilakukan diverifikasi dengan diskusi antara guru dengan teman sejawat.

Untuk mempermudah analisis data berkaitan dengan proses pembelajaran menulis karangan deskripsi dengan menggunakan pendekatan lingkungan digunakan indikator keberhasilan tercapainya tujuan pembelajaran menulis karangan deskripsi. Rambu-rambu proses pembelajaran dikembangkan dari langkah pembelajaran menulis karangan deskripsi dengan pendekatan lingkungan. Indikator keberhasilan penelitian ini ditunjukkan dengan beberapa hal berikut, yaitu: 1) terdapat peningkatan hasil belajar siswa dalam menulis karangan deskripsi, 2) terdapat peningkatan kinerja giru dalam proses pembelajaran dengan menerapkan pembelajaran menulis karangan deskripsi dengan menggunakan pendekatan lingkungan.

\section{HASIL DAN PEMBAHASAN}

Penggunaan pendekatan lingkungan dalam perencanaan pembelajaran menulis karangan deskripsi disusun dan diwujudkan dalam bentuk rencana pembelajaran. Rencana pembelajaran ini disusun secara kolaboratif antara peneliti dan guru kelas IV. Rencana pembelajaran tersebut disusun berdasarkan program semester II. Perencanaan tindakan terdiri dari tema, indikator, langkah-langkah, media, dan penilaian. Tema dalam pembelajaran yang diambil adalah lingkungan, dan sub temanya adalah lingkungan sekolah.

Pembelajaran dibagi menjadi 3 tahap kegiatan (1) tahap pramenulis (2) tahap penulisan, dan (3) tahap pascapenulisan.

\section{Siklus 1}

\section{Hasil Tahap Pramenulis}

Aspek kemampuan siswa menuliskan ciri-ciri dari objek yang diamati tiga berkualifikasi sangat baik (kelompok tinggi), empat berkualifikasi baik (tiga kelompok tinggi dan satu kelompok sedang), dan dua berkualifikasi cukup (kelompok rendah). Aspek kemampuan siswa mendeskripsikan objek yang telah diamati empat berkualifikasi baik (tiga kelompok tinggi dan satu kelompok sedang), lima berkualifikasi cukup (dua kelompok sedang dan tiga kelompok rendah). Aspek membuat kerangka deskripsi dari objek yang diamati karangan empat berkualifikasi sangat baik (tiga kelompok tinggi dan satu kelompok sedang), tiga berkualifikasi baik (satu kelompok sedang dan dua kelompok rendah), dua diberi kualifikasi cukup (kelompok rendah).

Berdasarkan uraian di atas pada kegiatan menuliskan ciri-ciri dari objek yang diamati, siswa dari kelompok tinggi sudah mampu mengurutkan 
seluruh gambar. Pada saat mendeskripsikan objek yang dipilih siswa dari kelompok tinggi telah bisa mengamati seluruh objek yang diamati dengan baik dan ide/gagasan yang disebutkan sudah sempurna. Pada saat

mendeskripsikan objek yang dipilih siswa dari kelompok tinggi sudah bisa membuat kerangka deskripsi sesuai dengan objek yang diamati, penulisannya sudah benar.
Tabel 1. Lembar Observasi Penerapan Pembelajaran Menulis Karangan Deskripsi dengan Pendekatan Lingkungan bagi Siswa Kelas IV SD Negeri 11 Pudung Kecamatan Ampek Nagari

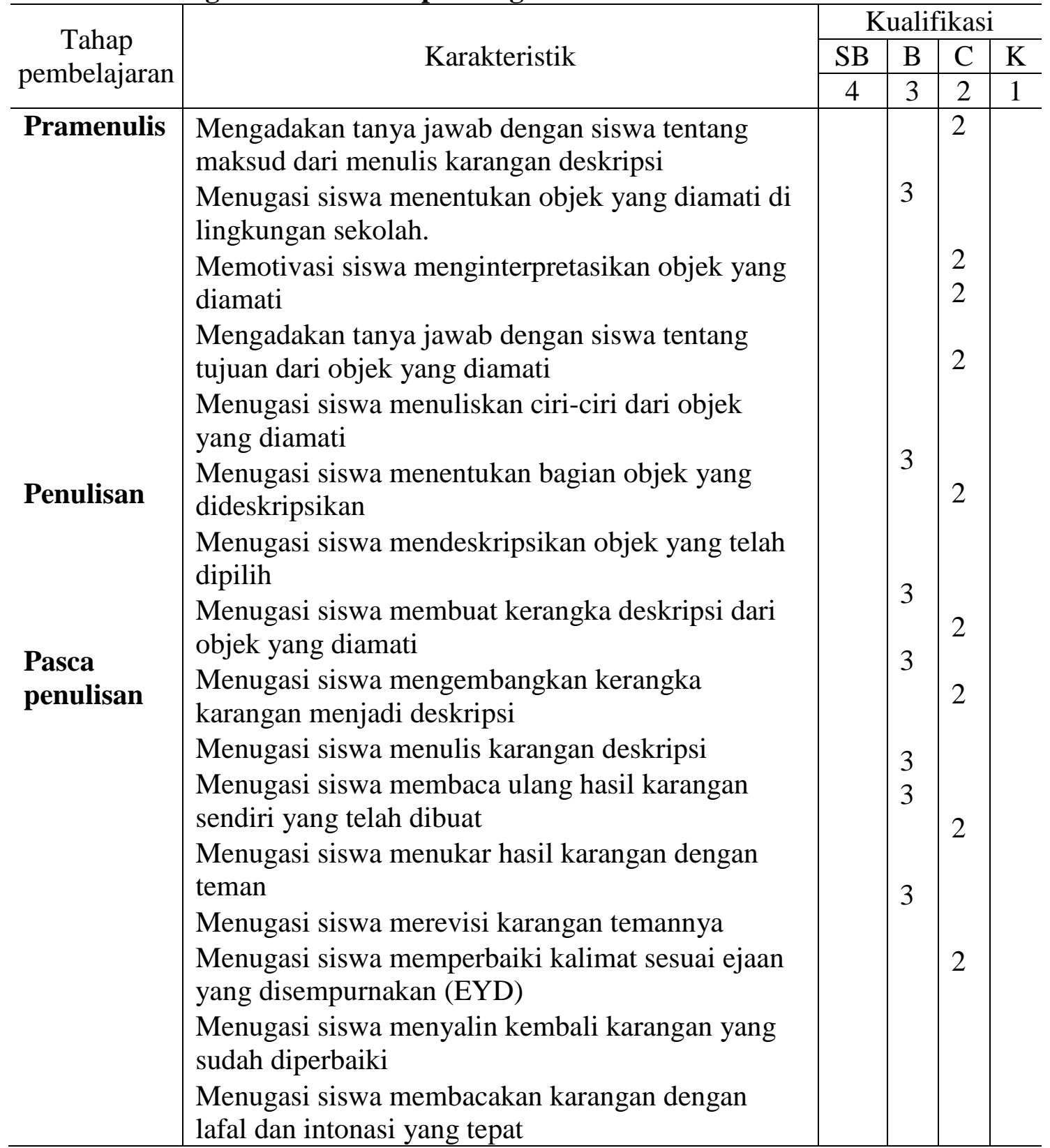

Keterangan:

SB : Sangat Baik

C : Cukup

B : Baik

K : Kurang 
Tabel 2. Lembar Observasi Penerapan Pembelajaran Menulis Karangan Deskripsi dengan Pendekatan Lingkungan bagi Siswa Kelas IV SD Negeri 11 Pudung Kecamatan Ampek Nagari

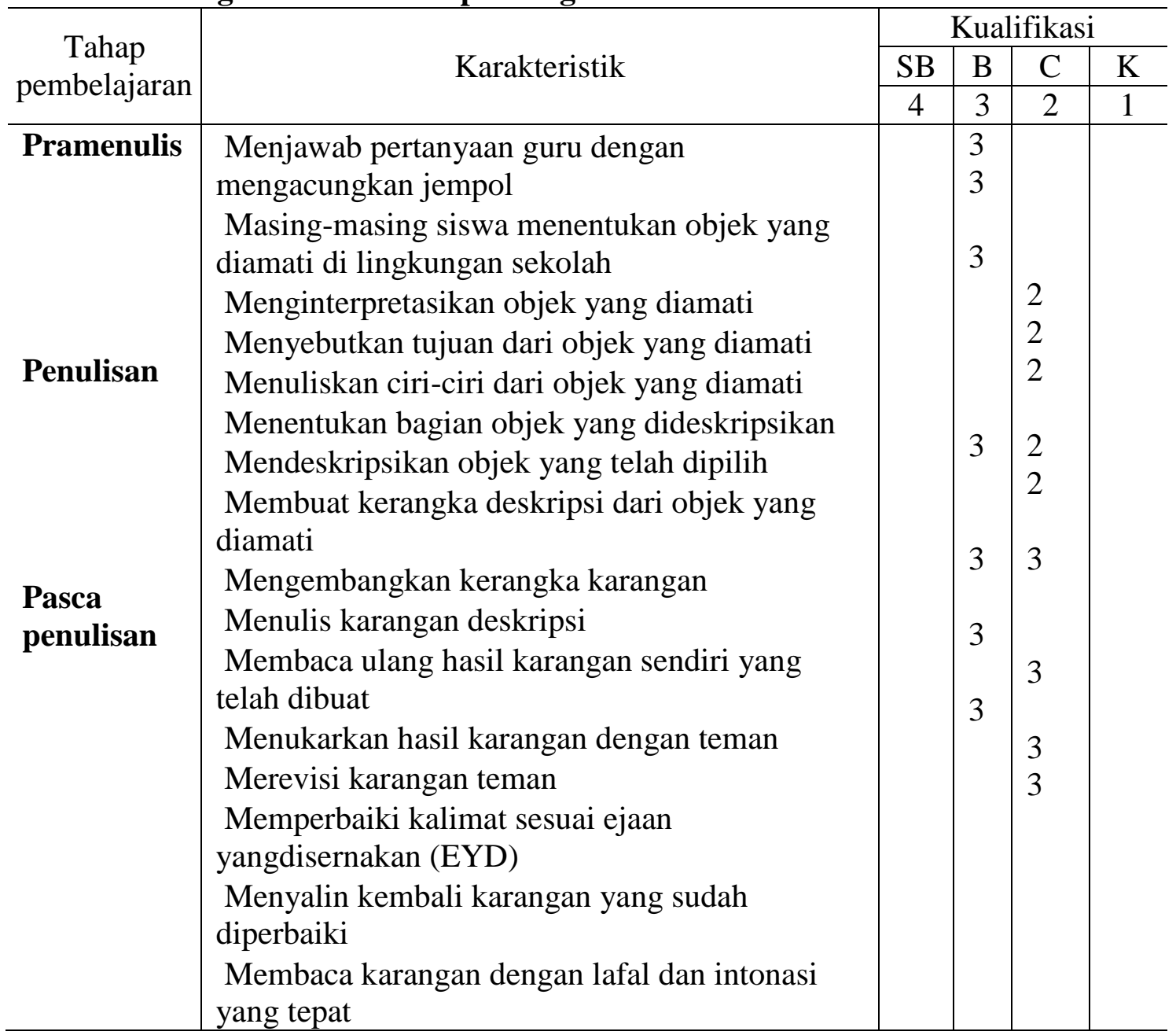

Keterangan:

$\begin{array}{lllll}\text { SB : Sangat Baik } & \{4\} & \text { B } & \text { : Baik } & \{3\} \\ \text { C : Cukup } & \{2\} & \text { K } & \text { : Kurang } & \{1\}\end{array}$

Siswa dari kelompok sedang sudah mampu menuliskan ciri-ciri sebagian besar dari dari objek yang diamati. Siswa dari kelompok ini sudah mampu mendeskripsikan sebagian besar objek yang telah dipilih, namun ide/gagasan yang disampaikan belum sempurna. Pada saat membuat kerangka deskripsi dari objek siswa dari kelompok sedang ini sudah bisa membuat kerangka deskripsi tapi kurang sesuai dengan objek.
Siswa dari kelompok rendah hanya mampu menuliskan ciri-ciri sebagian kecil objek. Pada saat mendeskripsikan objek siswa dari kelompok ini hanya mampu mendeskripsikan sebagian kecil objek, ide/gagasan yang disebutkan tidak sempurna. Pada saat membuat kerangka deskripsi kurang sesuai dengan objek.

\section{Hasil Tahap Penulisan}

Aspek gaya bahasa lima yang mendapat kualifikasi baik (tiga kelompok tinggi dan dua kelompok 
sedang) dan tiga yang mendapatkan kualifikasi cukup (satu kelompok sedang dan dua kelompok rendah), dan satu kelompok rendah yang mendapat kualifikasi kurang. Aspek pemilihan kata empat mendapat kualifikasi baik (satu kelompok tinggi dan satu kelompok sedang), dan tiga mendapat kualifikasi cukup (dua kelompok tinggi dan satu kelompok rendah), ada dua kelompok rendah yang mendapat kualifikasi kurang. Aspek struktur kalimat mendapatkan kualifikasi baik (satu kelompok tinggi dan dua kelompok sedang) dan empat mendapat kualifikasi cukup (dua kelompok tinggi, satu sedang, dan satu kelompok rendah). Aspek tanda baca satu kelompok tinggi yang memperoleh kualifikasi sangat baik, empat yang memperoleh kualifikasi baik(dua kelompok tinggi yang memperoeh nilai sedang, ada satu kelompok sedang yang memperoleh kualifikasi cukup, dan tiga dari kelompok rendah yang memperoleh nilai kurang.

Hasil karangan yang dibuat siswa masih ada pengulangan kata pada setiap kalimat. Sebagian besar kalimat sesuai dengan penggunaan ejaan, huruf kapital, tanda titik, dan tanda koma yang benar. Sebagian kecil idenya sudah sesuai dengan objek yang diamati, gaya bahasa yang digunakan lebih dari satu tetapi masih terdapat pengulangan kata. Sudah menggunakan pola paragraf tapi kurang wajar.

\section{Hasil Tahap Pascapenulisan}

Pada saat merevisi karangan teman, sebagian besar siswa belum mampu untuk merevisinya. Karena siswa belum memahami hal-hal yang perlu direvisi dalam karangan sehingga banyak siswa yang bermain-main. Hal ini disebabkan karena guru belum memberikan penjelasan mengenai hal-hal yang perlu direvisi dalam karangan.

\section{Siklus 2}

\section{Hasil Tahap Pramenulis}

Aspek kemampuan siswa menuliskan ciri-ciri dari gambar lingkungan rumah berkualifikasi sangat baik (tiga kelompok tinggi dan dua kelompok sedang), empat berkualifikasi baik (satu kelompok sedang dan tiga kelompok rendah). Aspek kemampuan siswa mendeskripsikan gambar lingkungan rumah dua berkualifikasi sangat baik (kelompok tinggi), enam berkualifikasi baik (tiga kelompok sedang dan tiga kelompok rendah). Aspek membuat kerangka deskripsi dari gambar lingkungan rumah lima berkualifikasi sangat baik (tiga kelompok tinggi dan dua kelompok sedang), empat berkualifikasi baik (satu kelompok sedang dan tiga kelompok tinggi.

Dari uraian di atas pada kegiatan menuliskan ciri-ciri dari gambar lingkungan rumah sesuai dengan urutannya yang benar, siswa dari kelompok tinggi sudah bisa menuliskan ciri-ciri dari gambar lingkungan rumah. Pada saat mendeskripsikan gambar lingkungan rumah di pajangkan siswa dari kelompok ini telah bisa mengamati seluruh isi gambar dengan baik, ide/gagasan yang disebutkan sudah sempurna. Pada saat membuat kerangka deskripsi dari gambar lingkungan rumah siswa dari kelompok tinggi sudah bisa membuat kerangka deskripsi dari 
gambar lingkungan rumah sesuai dengan gambar, penulisannyapun sudah benar.

Siswa dari kelompok sedang bisa menuliskan ciri-ciri dari gambar lingkungan rumah yang diamati bisa menyebutkan dari isi gambar. Tetapi hanya mampu mendeskripsikan sebagian besar isi gambar, ide/gagasan yang disampaikan kurang sempurna. siswa dari kelompok sedang mampu membuat kerangka deskripsi dari gambar sesuai dengan gambar. Sedangkan siswa dari kelompok rendah mampu menuliskan ciri-ciri sebagian besar dari gambar lingkugan rumah. Siswa dari kelompok rendah mampu mendeskripsikan sebagian besar dari gambar lingkungan rumah, tapi ide/gagasan yang disebutkan belum sempurna. Siswa dari kelompok rendah mampu membuat kerangka deskripsi tapi kurang sesuai dengan gambar.

Tabel 4. Lembar Observasi Penerapan Pembelajaran Menulis Karangan Deskripsi dengan Pendekatan Lingkungan bagi Siswa Kelas IV SDN 11 Pudung Kecamatan Ampek Nagari

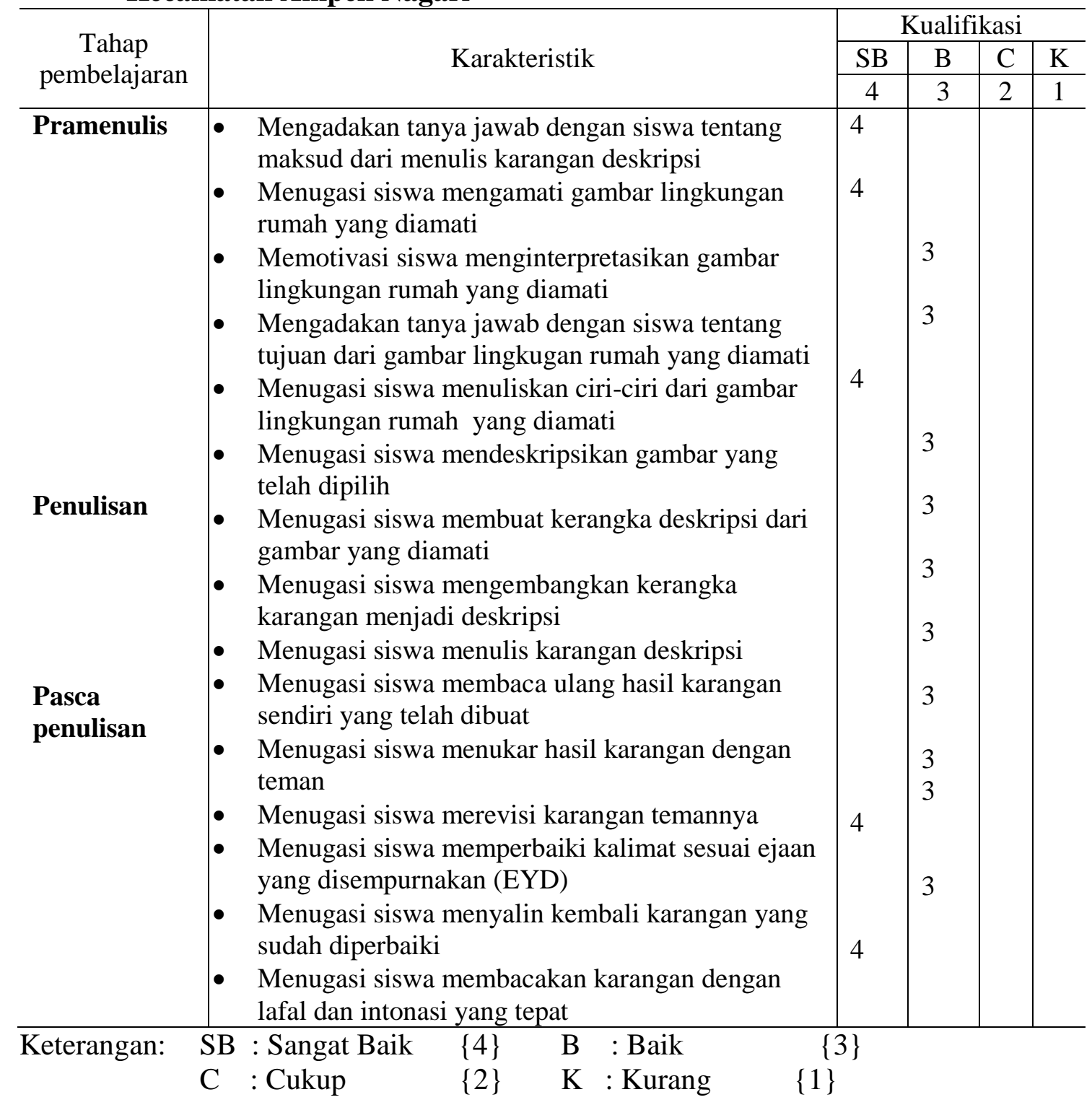


Tabel 5. Lembar Observasi Penerapan Pembelajaran Menulis Karangan Deskripsi dengan Pendekatan Lingkungan bagi Siswa Kelas IV SD Negeri 11 Pudung Kecamatan Ampek Nagari

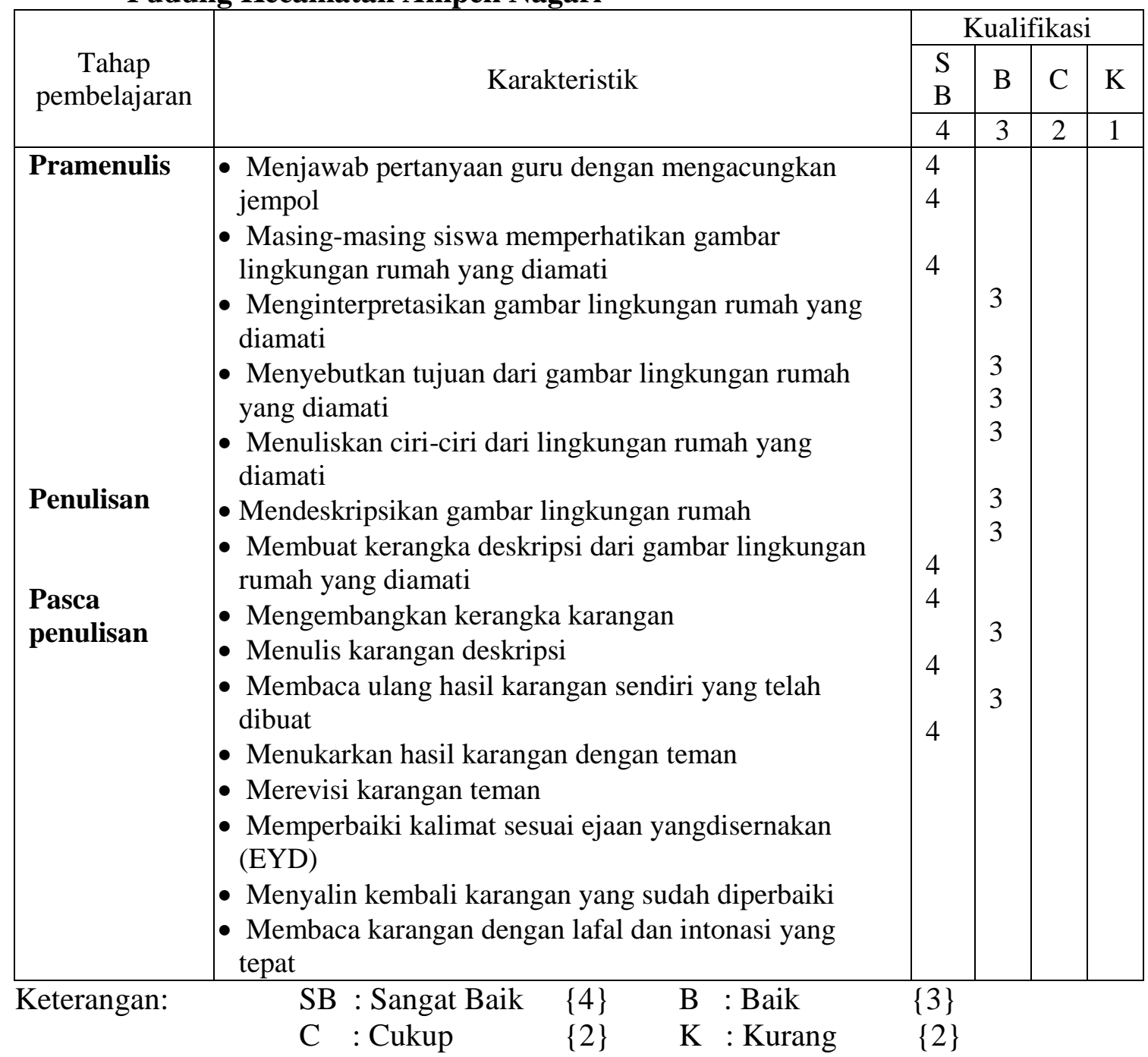

\section{Hasil Tahap Penulisan}

Tahap penulisan menulis karangan deskripsi adalah aspek ide/gagasan, empat mendapatkan kualifikasi sangat baik (tiga kelompok tinggi dan satu kelompok sedang), dan lima mendapatkan kualifikasi baik (dua kelompok sedang dan tiga kelompok rendah). Aspek gaya bahasa satu kelompok tinggi yang mendapat kualifikasi baik dan tiga yang mendapatkan kualifikasi baik (satu kelompok tinggi dan dua kelompok sedang), dan lima kelompok yang mendapat cukup (satu keompok tinggi,satu kelompok sedang dan tiga kelompok).

Aspek pemilihan kata tiga mendapat kualifikasi baik (satu kelompok tinggi dan dua kelompok sedang), dan enam mendapat kualifikasi cukup (dua kelompok tinggi, satu kelompok sedang, dan tiga kelompok rendah). Aspek struktur kalimat mendapatkan kualifikasi sangat baik satu kelompok tinggi, tiga kualifikasi baik (satu kelompok tinggi 
dan dua kelompok sedang), dan enam kelompok mendapat kualifikasi cukup (dua kelompok tinggi, satu sedang, dan tiga kelompok rendah).

Aspek tanda baca dua kelompok tinggi yang memperoleh kualifikasi sangat baik, lima yang memperoleh kualifikasi baik (satu kelompok tinggi yang memperoeh nilai bagus, ada tiga kelompok sedang yang memperoleh kualifikasi baik, dan satu dari kelompok rendah yang memperoleh nilai kurang). Berdasarkan hasil karangan siswa, masih ada sebagian kecil siswa yang menulis penggulangan kata pada setiap kalimat. Sebagian besar kalimat sesuai dengan penggunaan ejaan, huruf kapital, tanda titik, dan tanda koma yang benar. Idenya sudah sesuai dengan objek yang diamati, gaya bahasa yang digunakan lebih dari satu tetapi masih terdapat pengulangan kata. Sudah menggunakan pola paragraf yang tepat.

\section{Hasil Tahap Pascapenulisan}

Pada saat merevisi karangan teman, sebagian besar siswa sudah mampu untuk merevisinya. Siswa telah memahami hal-hal yang perlu direvisi dalam karangan, karena guru memberikan penjelasan mengenai halhal yang perlu direvisi dalam karangan. Akan tetapi guru belum memberikan bimbingan secara individu sehingga masih banyak siswa yang bertanya-tanya pada teman saat kegiatan merevisi. Aspek intonasi tiga mendapat kualifikasi sangat baik dan enam kualifikasi baik. Aspek ekspresi empat mendapat kualifikasi sangat baik dan lima mendapat kualifikasi baik.
Pada siklus II kekurangan pada siklus I sudah dapat diperbaiki. Guru melaksanakan pembelajaran dengan strategi pembelajaran secara klasikal, sehingga hal ini dapat lebih memotifasi siswa. Namun yang menjadi kekurangan pada saat pramenulis adalah siswa sulit membedakan mana yang kerangka dan mana yamng konsep, karena siswa kurang mengerti mana yang kerangka karangan dan mana yang konsep. Pada siklus II ini guru menjelaskan lagi kepada siswa mana yang kerangka dan mana yang konsep.

Kegiatan penulisan pada siklus II sudah terlaksana secara optimal. Segala kekurangan pada siklus I sudah teratasi disiklus II dimana guru telah memberikan bimbingan dan arahan pada siswa saat menulis karangan deskripsi.

Karangan yang dihasilkan siswa sudah baik, dalam satu paragraf siswa sudah bisa mengembangkannya menjadi empat sampai enam kalimat, kalimatnyapun sudah sempurna. Demikian juga dalam pemakaian huruf kapital, tanda titik dan tanda koma sudah hampir semuanya tepat. Cara penulisn paragraf siswa sudah memahami dengan baik. Pada siklus II hal ini sudah teratasi yaitu dengan memberikan penjelasan pada siswa baik secara klasikal maupun secara individual. Hal ini dinyatakan Daut (2008) "menyatakan pendekatan pembelajaran yang berusaha untuk meningkatkan keterlibatan siswa melalui pendayagunaan lingkungan sebagai program belajar, atau dengan kata lain kegiatan pembelajaran akan menarik perhatian siswa jika apa yang dipelajari diangkat dari lingkungan, sehingga apa yang dipelajari berhubungan dengan 
kehidupan dan berfaedah bagi lingkungannya".

Kegiatan pascapenulisan pada siklus 2 sudah berjalan dengan baik. Guru telah memberikan arahan beserta contoh bagaimana cara memperbaiki karangan. Akan tetapi guru belum memberikan bimbingan secara individu pada saat siswa merevisi karangan, sehingga masih ada siswa yang bertanya-tanya kepada temannya pada saat mengerjakan tugas. Guru sebaiknya membantu siswa pada setiap proses yang dilaluinya karena pendekatan lingkungan dalam menulis karangan deskripsi bukan hanya mengutamakan hasil tetapi juga mengutamakan proses. Sebelum siswa membacakan karangan ke depan kelas, guru terlebih dahulu memberikan contoh membaca karangan. Kemudian baru memanggil siswa secara bergiliran ke depan kelas. Namun pada siklus II ini guru kurang dalam memberikan penjelasan mengenai hal-hal yang perlu diperhatikan dalam membaca karangan seperti lafal, intonasi dan ekspresi. Sebaiknya guru menjelaskan secara rinci mengenai hal tersebut.

\section{PENUTUP}

Pendekatan lingkungan terbukti telah mampu meningkatkan kemampuan siswa dalam menulis karangan deskripsi. Pembelajaran dilaksanakan sesuai dengan perencanaan, pelaksanaan, dan penilaian. Pelaksanaan pembelajaran menulis karangan deskripsi memberikan simpulan bahwa pembelajaran dilakukan melalui proses menulis dengan tahapan berikut: (a) pramenulis, (b) penulisan, dan (c) pascapenulisan. Proses tersebut disimpulkan sebagai berikut.
Tahap pramenulis dilaksanakan seiring dengan tahapan penulisan. Tahap pramenulis merupakan awal dari kegiatan pembelajaran menulis karangan deskripsi. Pembelajaran dilaksanakan sebagai berikut. Pertama, kegiatan menyiapkan siswa pada awal pembelajaran sangat penting dilakukan untuk menciptakan prakondisi siswa untuk menerima pembelajaran. Kedua, siswa menentukan objek yang diamati. Ketiga, membuat kerangka karangan deskripsi.

Pembelajaran menulis karangan pada tahap penulisan dilakukan dengan menugasi siswa mengembangkan kerangka karangan. Karangan dikembangkan dengan kata dan kalimat yang tepat dan memperhatikan penggunaan ejaan, huruf kapital, tanda titik, dan tanda koma. Selanjutnya siswa menulis karangan menjadi deskripsi.

Pembelajaran menulis karangan deskripsi pada tahap pascapenulisan dilakukan dengan menugasi siswa merevisi dengan memperhatikan EYD yang tepat. Kegiatan merevisi dilakukan dengan teman sebangku. Sebelum kegiatan merevisi dilakukan guru terlebih dahulu menjelaskan hal-hal yang perlu diperhatikan dalam pengoreksian. Pada saat merevisi guru juga melakukan bimbingan individu dengan mendatangi tempat duduk siswa. Setelah merevisi dilakukan selanjutnya siswa ditugaskan untuk memperbaiki kembali karangan yang telah selesai direvisi. Selanjutnya guru menugasi siswa untuk membacakan karangan ke depan kelas.

Penilaian dalam pembelajaran menulis karangan deskripsi dengan pendekatan lingkungan, guru lebih 


\section{Jurnal Pelangi}

mampu dilakukan secara komprehensif. Guru tidak saja melakukan penilaian hasil tetapi juga melakukan penilaian proses mulai dari tahap pramenulisan, penulisan, dan pascapenulisan. Penilaian proses direkam melalui pedoman pengamatan analisis kegiatan siswa dalam pembelajaran. Sedangkan penilaian hasil dilakukan menganalisis hasil pada tahap penulisan karangan deskripsi dengan menggunakan panduan penilaian kemampuan menulis karangan deskripsi dengan pendekatan lingkungan.

Beberapa saran yang dapat dikemukakan berkaitan dengan hasil penelitian pembelajaran menulis karangan deskripsi dengan pendekatan lingkungan dipaparkan sebagai berikut:

1. guru kelas IV SD agar menggunakan hasil penelitian ini, yaitu menggunakan pendekatan lingkungan sebagai pendekatan alternative dalam pembelajaran menulis karangan deskripsi.

2. guru SD agar membimbing siswa dalam mengamati atau menentukan objek yang akan dideskripsikan, karena hal ini sagat membantu siswa dalam mengungkapkan ide atau gagasannya.

3. guru SD agar membimbing siswa saat mengembangkan karangan. Karena siswa kelas IV SD adalah penulis lanjutan dalam menulis karangan, karena di kelas III siswa sudah memulai mengarang. Akan tetapi masih perlu juga bimbingan dan arahan dari guru.

4. guru SD untuk membimbing siswa merevisi kembali karangan yang telah dibuatnya, baik dari segi kata, huruf kapital, tanda titik maupun tanda komanya. Agar kesalahankesalahan yang sama tidak terulang lagi pada kegiatan-kegiatan pembelajaran berikutnya dan yang lebih penting karangan yang dihasilkan siswa lebih bagus.

\section{UCAPAN TERIMA KASIH}

Terbitnya tulisan ini tidak terlepas dari bantuan berbagai pihak, untuk itu penulis ucapkan terima kasih yang sebesar-besarnya kepada Pihak STKIP PGRI Sumatera Barat khususnya pengelola jurnal Pelangi yang telah memberikan kesempatan kepada penulis untuk menulis di Jurnal Pelangi.

\section{DAFTAR PUSTAKA}

Akhadiah Mk.Dkk. (1998). Menulis I : Buku Materi Pokok EPNA 7203/ 2 sks Modul 1-4. Jakarta : Depdikbud, Dirjen Pora Bagian Proyek Penataran Guru SLTP Setara D II.

Costa.(1985). http://www.kelasmenulis .com/blog//2007/01/pelatihanoli ne_penulisan_des_httme, (Diakses 10 maret 2008).

Djuanda Dadan. (2002). Pembelajaran bahasa Indonesia yang Komunikatif dan Menyenangkan. Jakarta.

Dimyati. (2002). Belajar dan Pembelajaran. Jakarta : PT Asdi mahasatya.

Depdiknas. (2006). Kurikulum Tingkat Satuan Pendidikan Jenjang Pendidikan Dasar. Jakarta: BNSP 
Depdiknas. (2001). Mengarang di Sekolah Dasar. Jakarta : Depdiknas.

Eny Wati. (2004). Kualifikasi Nadya Indonesia. Yogyakarta:MGMD Bahasa dan Sastra Indonesia.

Elfia Sukma. 2006. Peningkatan Kemampuan Menulis Puisi Siswa Kelas $V$ SD Negeri Sumber Sari III Malang dengan Strateg pemetaan Pikiran. Tesis tidak diterbitkan. Malang: Program Pasca Sarjana Universitas Negeri Malang.

Gay.(http://66.218.69.11//search/charce/ ei=UTf $88 p=$ penilian $=$ dalam $=m e$ nulis\&fr $=y f p t 309 \& f p=I D \& U=w$ ww.geocfies.com/kheru2006/i.ht $\underline{m \& w=p e n i l a i a n+d a l a m+m e n u l i}$ $\underline{\mathrm{s} \&=B i S M S P H}$ QiS\&icp=id.i). (diakses 28 Maret 2008)

Haryadi. (1996). Peningkatan Keterampilan Berbahasa Indonesia. Jakarta : Depdikbud.

Ischak. (2002). Pendidikan IPS di SD. Jakarta: Derpdikbud.

Lubis Grafura. (2007). Deskripsi dan Narasi. Karya Djalka Lodhang No.16 \& No 17, edisi sabtu, 17 September 2005, tahun XXXV,hal.4.

Muslich. http://muslich-m.blogspot.com /2007/08/jenis-karangan-dan langkah-langkah.html. (Diakses 30maret 2008).
Moejdiono. (1992) Strategi Belajar Mengajar. Jakarta: Depdikbud.

Muslich (http://muslich-m.blogspot.com /2007/08/jenis-karangan-danlangkah-langkah.html)

Nasution Noehi. (2003). Pendidikan IPA di SD. Jakarta: Universitas Terbuka.

Ritawati Mahyudin. (2003). Makalah Pembelajaran Bahasa dan Sastra di Kelas-Kelas Tinggi Sekolah Dasar. Padang: Universitas Terbuka.

Rusyana. (1988). http://www.kelas menulis.com/blog//2007/01/ pelatihanoline_penulisan_des_ httme. (Diakses 10 maret 2008).

Rustam Mundilato. (2004). Penelitian Tindakan Kelas. Jakarta: Depdiknas tersedia dalam. http://www.klinik pembelajaran.com/booklet/penel itian tindakan kls.pdf.(diakses 18 februari 2008).

Saleh Abbas. (2006). Pembelajaran Bahasa Indonesia Yang Efektif di Sekolah Dasar. Jakarta : Depdiknas.

Suparno. Dkk. (2007). Keterampilan Dasar Menulis. Jakarta : Unversitas Terbuka.

Semi. M.Atar. (1989). Menulis Efektif. Padang.: Sri Oharma. (Skipsi yusnal Hayati. UNP 2004). (Laruni, M. Yasin. UNP 2003) dan (Netti M. UNP 2007). 